\title{
Islet Transplantation Challenge - Human Islet Longevity: A Potential Solution from Bone Marrow Cells
}

\section{Lu-Guang Luo*}

Roger Williams Medical Center, Boston University, Providence, Rhode Island 02908, USA

\section{Islet Transplantation: The Problem of Islet Survival}

The occurrence of diabetes mellitus has increased steadily worldwide [1]. Improvements in the immunosuppressive regimen have made clinical islet transplantation a feasible choice which to treat type 1 diabetes [2]. However, efforts toward routine islet cell transplantation have been hindered not only by scarce islet availability but also by low rates of post-transplantation islet survival and function $[3,4]$. The number of islets generally required to achieve insulin independence is 12000 islet equivalents per $\mathrm{kg}$ of recipient's body weight, and this number is usually obtained by transplanting more than one islet preparation per patient [5]. Early graft loss resulting from repeated transplantations of islets [6] is a major component of islet primary nonfunctioning, which occurs in syngeneic islet transplantation [7] as well as T-cell activation [8,9]. Large numbers of islets are destroyed, and only a small proportion are successfully engrafted after transplantation $[4,10,11]$. These findings suggest that poor islet viability—not just allograft rejection and recurrence of autoimmunity-may contribute to early-stage loss of islet function. In experimental models of syngeneic islet transplantation, up to $60 \%$ of islet cell mass undergoes apoptosis, and half of this loss occurs within the first 3 days after transplantation [12]. Functional islet mass is reduced even in successfully transplanted recipients compared with healthy people. These failures-the result of islet damage before transplantation-are the major barrier to the widespread use of islet transplantation.

\section{Factors Contribute to Functional Failure of Isolated Islets}

Reduced viability and functional impairment caused by stress during isolation and implantation $[13,14]$ are major reasons for the need to transplant a large number of islets to obtain desired results. Proinflammatory cytokines such as interleukin-1 $\beta$ (IL-1 $\beta$ ), tumor necrosis factor-alpha (TNF- $\alpha$ ), interferon- $\gamma$ (INF- $\gamma$ ), cyclooxygenase- 2 (COX-2), and nitric oxide (NO) as well as chemokines secreted from islets play an important role in islet survival in vitro and at different stages after transplantation [15]. Recruitment of activated leukocytes toward islets as a result of cytokine and chemokine secretion could cause islet injury and participate in presenting foreign antigens to the macrophages, which leads to acute immune response and death or impairment of $\beta$ cells. Thus, the amount of cytokines released by donor pancreatic islets is directly related to islet survival after isolationincluding the rate at which pancreatic islet tissue undergoes apoptosis in vitro [16,17] —and transplantation outcome in the recipient [18]. Blockading apoptosis through the inhibition of cytokines could help protect pancreatic islets from either cell-mediated or non-cell-mediated destruction [19]. Several approaches have been used to examine this hypothesis. Isolated human islets have been shown to secrete TNF- $\alpha$, IL-1 $\beta$, IL-6, and nitric oxide. Secretion of these mediators was shown to be augmented by stimulation of the islets with IL-1 [3] and others [20]. IL- $1 \beta$ is considered to be the key initiator of inflammatory response and one of the proinflammatory cytokines that may mediate primary nonfunction of islets in vitro and have the greatest effect on outcome post-transplantation [21].

\section{Approaches to Ensuring Islet Survival}

Numerous efforts have been made to improve islet cytoprotectionthat is, to ensure islet survival, function and transplant success [19]. Chemical-based strategies for islet cytoprotection, such as the early application of perfluorocarbons to the organ preservation solution (twolayer method) allows for increased availability of oxygen to the tissue. This step permits increased adenosine triphosphate (ATP) content in the organ $[11,22,23]$. Use of additives in the culture media (antioxidants, hormones, etc.) may result in reduced islet cell death, improved islet recovery after isolation, and better function, representing a minimally invasive strategy for the optimization of islet engraftment. Molecular biological approaches to achieve islet cytoprotection have used various vectors (including viruses) to transfer genes that may inhibit apoptosis or increase growth factors [24-26]. Delivery of cytoprotective proteins by protein transduction allows delivery of proteins/peptides fused to small cationic cell-penetrating peptides known as protein transduction domains to cells or tissues [27]. However, the goal of maintaining islet viability has not yet been fully achieved by these efforts.

\section{The Microenvironment of The Pancreas Facilitates Islet Survival and Function}

The microenvironment of the pancreas enables islets to be immunized from insults to allogeneic tissue and permits repair of islet injury and regeneration of functional pancreatic endocrine tissue. The finding that pancreatic transplantation has resulted in better insulin independence than islet transplantation alone [28,29] supports the notion that islet injury and microenvironment loss from the isolation process may be the major cause of islet death after transplantation. Another example of microenvironmental effect on islet $\beta$ function is that Mist1 null mice exhibit small islet size and aberrant islet function even though Mist1 has been identified only through expression in exocrine cells_-such as acinar cells-not directly related to islet $\beta$ cells [30-33]. The absence of Mist1 alters the pancreatic microenvironment, which generates unsuitable circumstances for islet development. The successful use of bone marrow to repair damaged tissues encourages the use of stem cells to create a microenvironment for islet longevity,

*Corresponding author: LuGuang Luo, Roger Williams Hospital, Boston University School of Medicine, 825 Chalkstone Avenue, Providence, RI 02908 USA, Tel: +1401 456 5344; Fax: +1 401456 5759; E-mail: Lluo@rwmc.org

Received July 10, 2012; Accepted July 12, 2012; Published July 14, 2012

Citation: Luo LG (2012) Islet Transplantation Challenge - Human Islet Longevity: A Potential Solution from Bone Marrow Cells. J Bioanal Biomed 4: e107. doi:10.4172/1948-593X.1000e107

Copyright: (c) 2012 Luo LG. This is an open-access article distributed under the terms of the Creative Commons Attribution License, which permits unrestricted use, distribution, and reproduction in any medium, provided the original author and source are credited. 
which is further supported by the accumulating evidence based on investigations into the regenerative capacity of stem cell tissue, of stem cells' low immunogenic thresholds and production of homing and trophic factors promoting vasculogenesis.

\section{Stem Cells and Islet $\beta$ Cell Function}

For diabetes therapy, it is not clear whether it will be sufficient to produce only $\beta$ cells - the islet cells that manufacture insulin-or whether other types of islet cells are also necessary. B cells isolated without other types of islet cells are less responsive to changes in glucose concentration than intact islet clusters made up of all islet cell types. This may be the major reason why different sources of stem cells have been proposed for the production of $\beta$ cells; in practice, however, fully functional islet cells have not yet been derived from stem cells. Bone marrow-derived stem cells have been considered the best-characterized stem cell source, but current research suggests that these cells do not differentiate into $\beta$ cells in vivo, although they can support pancreatic growth in vivo and can be manipulated in vitro to differentiate into $\beta$ cells [34]. However, pure bone marrow sub stem population pretreated by cytokines are able to generate insulin positive cells in vivo [35] which Bone marrow-derived stem cells can migrate towards a site of damage and differentiate under the influence of factors from the microenvironment (e.g. cell-cell, cell-extracellular matrix interactions and growth factors) [36].

\section{Bone Marrow Cells can Regenerate the Pancreatic Microenvironment}

Animal studies of how bone marrow maintains hematopoietic stem cell function indicate that stromal cells were critically important for these stem cells, preventing apoptosis and providing signals for proliferation and differentiation, at times in coordination with the internal clock of the primitive cell. Stromal cells act through a number of mediators, cytokines, adhesion molecules, peptides, hormones, and other molecules. These cytokines and chemokines include the colony-stimulating factors; interleukins- $1,-6,-7$, and -8 (IL-1, IL-6, IL-7, IL-8); leukemia inhibitory factor; stem cell factor; flt3 ligand; hepatocyte growth factor; thrombopoietin; insulin-like growth factor-1; transforming growth factor $\beta$ (TGF- $\beta$ ); tumor necrosis factor- $\alpha$ (TNF- $\alpha$ ); $\gamma$-interferon-inducible protein-10 (IP-10); monocyte chemoattractant protein-1 (MCP-1); and stromal-derived factor- 1 . TGF- $\beta$ is the most potent inhibitor of hematopoiesis, which induces expression of inhibitory chemokines such as MCP-1 and IP10 and decreases expression of stromal adhesion molecules. Together these signaling proteins make up the stem cell niche, a concept first expounded by Schofield in 1978 [37]. Schofield posited that when hematopoietic stem cells are fixed in a specific microenvironment they will maintain a stable potential for self-renewal, and that commitment to different hematopoietic lineages will be regulated by specific niches. The generation of continuous cloned murine marrow lines has confirmed the existence of niches [37]. Human stromal cells have been seen to home to and promote repair of pancreatic islets in NOD/ scid mice, but no human cells have been detected in animal pancreases [38]. Therefore, improved pancreatic function in the mice suggests that stromal cells are able to establish a microenvironment conducive to the development of pancreatic islet $\beta$ cells [38]. Friedenstein et al. provided the earliest evidence that adult bone marrow contains endothelial stem cells and primitive mesenchymal cells [39]. It is now well documented that bone marrow mesenchymal stem cells identified using positive markers for CD105 (SH2) and CD73 (SH3 and SH4) have the ability to differentiate into multiple lineages, including osteogenic [40], adipogenic [41], and chondrogenic tissues [42]. Several mechanisms enable donor mesenchymal cells to evade host allogeneic responses $[43,44]$. Bone marrow mesenchymal cell-induced immunorejection tolerance of islet allograft has been observed in vivo through the induction of chimerism in the recipient [45]. Further research into these microenvironments will enable the development of interventions that reduce or prevent immunoreactions resulting in islet apoptosis or necrosis and the functional impairment of $\beta$ cells [46].

\section{Bone Marrow and Islet Compatibility}

Although it has been reported that bone marrow transplantation benefits diabetic animals in vivo, much debate surrounds the derivation of insulin-producing cells from bone marrow cells [47]. Bone marrow generated cells lack important characteristics of normal $\beta$ cells, and much more information about the several possible mechanisms of regeneration which is needed. To name just one example, mice subjected to $\beta$ cell damage were injected with labeled bone marrow cells. While no bone marrow cells were shown to develop into insulin-producing cells, many bone marrow-derived endothelial cells were present in areas of injury. The data therefore indicate that bone marrow-derived endothelial progenitor cells respond to $\beta$ cell injury in the pancreas and that this mechanism might be beneficial in repairing islet damage or improving islet survival [48]. However, pure stem cell subpopulation from bone marrow cells pretreated under certainly condition can differentiate into positive insulin cells in pancreas in vivo [35]. The notion is further supported by bone marrow's role in pancreatic islet development during the neonatal period and after pancreatic injury [49].

\section{Human Islet is an Ideal Model in which to Study Fundamental Mechanisms of Islet Longevity}

Recent evidence indicates that human islet differ significantly in morphology from islet in other species [50,51], which suggests that there is functional variation. If morphological variation between human islet and that of other species determines functional difference, therefore, human islets are probably the best model for determining how to ensure human islet survival in vitro and in vivo. In addition, we can examine mechanisms that regulate the islet survival process (or death process) relatively unencumbered by islet death-related pathologies, which are frequently confounding factors in diabetic studies. The knowledge generated from human islet model may also contribute to understanding the development of diabetes and possible strategies to prevent it.

\section{The Potential Mechanisms of Two Models of Bone Marrow Support of Islet Longevity}

We have previously reported that allogeneic bone marrow supports human islet survival and function for more than six months [52]. Bone marrow reduces human islet release of IL- $1 \beta$, thus abridging the apoptotic process in cultured islets (observed in our previous studies). Subsequent enlargement of cocultured islets suggests islet reconstitution and regeneration in vitro [53]. IL-1 $\beta$ expression and release in human islet $\beta$ cells induced by islet injury can cause cell death by activating nuclear factor kappa B (NF- $\kappa \mathrm{B}$ ) and Fas apoptotic cascades to suppress islet function and to destroy $\beta$ cells $[54,55]$. We propose two possible outcomes from reconstituting islets with allogeneic bone marrow in regard to islet longevity. In the template model, bone marrow cells transdifferentiate into islet cells after long-term culture, including bone 
marrow progenitor cells, convert into epithelia and endothelia to form a biological islet capsule and/or $\alpha, \beta$, or other endocrine cells [56]. Such cells would also have the bone marrow donor's HLA character, which will abrogate the induction of rejection if bone marrow-derived cells dominate the majority of reconstituted islets and the recipient is the bone marrow donor. In the nutrient model, bone marrow provides a supportive microenvironment by releasing/paracrine cytokines that stimulate islet cell regeneration and inhibition of the apoptotic process. In this model less change in the islets' immunological characteristics would be expected.

When human bone marrow is cocultured with islets, bone marrowderived marrow stromal cells and/or lineage-positive cells release cytokines and other growth factors that stop the apoptotic process and stimulate islet cell self regeneration. Bone marrow-derived stem cells and/or mesenchymal cells, on the other hand, repair islet injury and aid islet reconstitution. By these two proposed models, bone marrow creates a microenvironment for islet regeneration that includes the formation of capsule-like tissue around islets and the potential for vascularization that will improve tolerance in vitro and implantation in vivo (See figure 1).

If bone marrow cells dominate the reconstituted islet population (template model), the islet tissue will have tolerance to bone marrow donor in vivo. If bone marrow cells only release factors to improve islet reconstitution (nutrient model), the reconstituted islets will have less tolerance to bone marrow donor cells in vivo. If the two models play an equal role, islet tissue implanted into bone marrow donor will improve tolerance (Figure 1).

\section{Cytokines TNF- $\alpha$ and IP-10 Play a Role in the Interaction of Bone Marrow and Islet Cells}

We have proposed two mechanisms by which bone marrow culture may support repair and survival of human islet cells in vitro. We further propose that two cytokine/chemokines, tumor necrosis factor $\alpha($ TNF- $\alpha)$ and chemokine IFN-gamma-inducible protein of $10 \mathrm{kDa}$ (IP-10/CXCL10), may initiate the processes. TNF $\alpha$ plays an important known role in islet cell death by stimulating cellular apoptotic cascades. However, TNFa's ability to generate an autocrine tumor-promoting network in epithelial ovarian cancer cells by stimulating the release of other cytokines and growth factors [57] from bone marrow suggests that TNF- $\alpha$ may also be the initiator of islet-supporting growth factor and cytokine release in bone marrow-derived lineage-positive and stromal cells, as outlined in our nutrient model. As the recruiter of

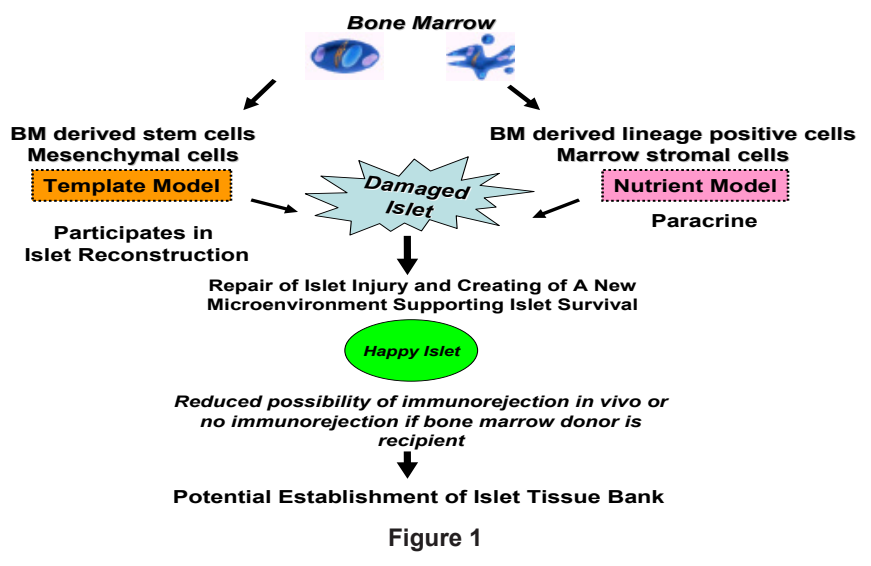

activated $\mathrm{T}$ lymphocytes to sites of inflammation by interaction with the G-protein-coupled receptor CXCR3, IP-10 has ability to stimulate cell migration by forming oligomers for presentation on endothelial cells and subsequent transendothelial migration, an essential step for lymphocyte recruitment in vivo [58]. However, high expression of CXCR3 in hematopoietic stem cells (HSCs) did not induce HSC migration [59], but IP-10 with overexpression of its receptor CXCR3 enhanced neural progenitor cell migration in vitro [60], suggesting that IP-10 may have other functions. We hypothesize that IP-10 may serve as an initiator for bone marrow mesenchymal cell differentiation into endothelia or epithelia, as outlined in our template model.

\section{Conclusion and Prospect for Future}

We propose that bone marrow can be a solution for human islet $\beta$-cell longevity through cell-cell contact to participate in islet reconstitution and secretes or paracrine cytokines that appear to reduce production and release of inflammatory factors from islets, thus eliminating islet apoptosis. These events stimulate islet regeneration, recovery of insulin production, and eventually increase in islet mass. Bone marrow reconstituted human islet will have several important benefits: (a) more $\beta$-cells in islets will be generated from a limited resource; (b) islet proinflammatory factor production and release will be eliminated, resulting in decreased islet cell apoptosis and possible reduction of immunorejection in vivo; (c) islet remained survival will provide possibility for new approach to keeping islet longevity in vitro and in vivo.

\section{Acknowledgements}

This study was funded by National Center for Research Resources (COBRE, 5P20RR018757-10) and the National Institute of General Medical Sciences (8 P20 GM103414-10) from the National Institutes of Health, Juvenile Diabetes Research Foundation International (JDRF) foundation 1-2007-180 and Roger Williams Hospital Research fund.

\section{References}

1. Mathis D, Vence L, Benoist C (2001) Beta-Cell death during progression to diabetes. Nature 414: 792-798.

2. Shapiro AM, Ricordi C, Hering BJ, Auchincloss H, Lindblad R, et al. (2006) International Trial of the Edmonton Protocol for Islet Transplantation. N Engl J Med 355: 1318-1330.

3. Rother KI, Harlan DM (2004) Challenges facing islet transplantation for the treatment of type 1 diabetes mellitus. J Clin Invest 114: 877-883.

4. Ryan EA, Lakey JR, Shapiro AM (2001) Clinical results after islet transplantation J Investig Med 49: 559-562.

5. Pileggi A, Ricordi C, Alessiani M, Inverardi L (2001) Factors influencing Islet of Langerhans graft function and monitoring. Clin Chim Acta 310: 3-16.

6. Davalli AM, Scaglia L, Zangen DH, Hollister J, Bonner-Weir S, et al. (1996) Vulnerability of islets in the immediate posttransplantation period. Dynamic changes in structure and function. Diabetes 45: 1161-1167.

7. Nagata M, Mullen Y, Matsuo S, Herrera M, Clare-Salzler M (1990) Destruction of islet isografts by severe nonspecific inflammation. Transplant Proc 22: 855856.

8. Chahine AA, Stoeckert C, Lau HT (1995) Local immunomodulation to promote co-stimulatory blockade. Clin Transplant 9: 215-218.

9. Kaufman DB, Platt JL, Rabe FL, Dunn DL, Bach FH, et al. (1990) Differentia roles of Mac-1+ cells, and CD4+ and CD8+ T lymphocytes in primary nonfunction and classic rejection of islet allografts. J Exp Med 172: 291-302.

10. Johansson H, Lukinius A, Moberg L, Lundgren T, Berne C, et al. (2005) Tissue factor produced by the endocrine cells of the islets of Langerhans is associated with a negative outcome of clinical islet transplantation. Diabetes 54: 1755 1762 
Citation: Luo LG (2012) Islet Transplantation Challenge - Human Islet Longevity: A Potential Solution from Bone Marrow Cells. J Bioanal Biomed 4: e107. doi:10.4172/1948-593X.1000e107

11. Miyamoto M, Morimoto Y, Balamurugan AN, Kawakami Y, Gu Y,et al. (2000) Improvement of modified two-layer preservation method (PFC/Kyoto solution) in islet isolation from breeder pigs. Transplant Proc 32: 1660-1661.

12. Barshes NR, Wyllie S, Goss JA (2005) Inflammation-mediated dysfunction and apoptosis in pancreatic islet transplantation: implications for intrahepatic grafts. J Leukoc Biol 77: 587-597.

13. Ricordi C, Strom TB (2004) Clinical islet transplantation: advances and immunological challenges. Nat Rev Immunol 4: 259-268.

14. Stock PG, Bluestone JA (2004) Beta-cell replacement for type I diabetes. Annu Rev Med 55: 133-156.

15. Ehrnfelt C, Kumagai-Braesch M, Uzunel M, Holgersson J (2004) Adult porcine islets produce MCP-1 and recruit human monocytes in vitro. Xenotransplantation 11: 184-194.

16. Amrani A, Verdaguer J, Thiessen S, Bou S, Santamaria P (2000) IL-1alpha, IL-1beta, and IFN-gamma mark beta cells for Fas-dependent destruction by diabetogenic CD4(+) T lymphocytes. J Clin Invest105: 459-468.

17. Corbett JA, Sweetland MA, Wang JL, Lancaster JR, McDaniel ML (1993) Nitric oxide mediates cytokine-induced inhibition of insulin secretion by human islets of Langerhans. Proc Natl Acad Sci USA 90: 1731-1735.

18. Schroppel B, Zhang N, Chen P, Chen D, Bromberg JS, et al. (2005) Role of donor-derived monocyte chemoattractant protein-1 in murine islet transplantation. J Am Soc Nephrol 16: 444-51.

19. Pileggi A, Fenjves ES, Klein D, Ricordi C, Pastori RL (2004) Protecting pancreatic beta-cells. IUBMB Life $56:$ 387-394

20. Piemonti L, Leone BE, Nano R, Saccani A, Monti P, et al. (2002) Human pancreatic islets produce and secrete MCP-1/CCL2: relevance in human islet transplantation. Diabetes 51: 55-65.

21. Gürol AO, Kurşun AO, Süzergöz F, Küçüksezer UC, Kiran B, et al. (2005) Peritransplant and long-term secretion of interleukin-1beta in cyclosporine treated syngeneic rats allografted with islets of langerhans. Transplant Proc 37: $2375-2378$.

22. Tanioka Y, Sutherland DE, Kuroda Y, Gilmore TR, Asaheim TC, et al (1997) Excellence of the two-layer method (University of Wisconsin solution/ perfluorochemical) in pancreas preservation before islet isolation. Surgery 122 : 435-441

23. Tsujimura T, Kuroda Y, Churchill TA, Avila JG, Kin T,et al. (2004) Short-term storage of the ischemically damaged human pancreas by the two-layer method prior to islet isolation. Cell Transplant 13: 67-73.

24. Fenjves ES, Ochoa MS, Gay-Rabinstein C, Molano RD, Pileggi A, et al. (2004) Adenoviral gene transfer of erythropoietin confers cytoprotection to isolated pancreatic islets. Transplantation 77: 13-18.

25. Kapturczak MH, Flotte T, Atkinson MA (2001) Adeno-associated virus (AAV) as a vehicle for therapeutic gene delivery: improvements in vector design and vira production enhance potential to prolong graft survival in pancreatic islet cell transplantation for the reversal of type 1 diabetes. Curr Mol Med 1: 245-258.

26. Contreras JL, Bilbao G, Smyth C, Eckhoff DE, Xiang XL, et al. (2001) Gene transfer of the $\mathrm{Bcl}-2$ gene confers cytoprotection to isolated adult porcine pancreatic islets exposed to xenoreactive antibodies and complement. Surgery 130: $166-174$

27. Wadia JS, Dowdy SF (2002) Protein transduction technology. Curr Opin Biotechnol 13:52-56.

28. Fellmer $\mathrm{P}$, Lanzenberger $\mathrm{K}$, Ulrich $\mathrm{F}$, Pascher A, Langrehr J, et al. (2007) Complication rate of pancreas retransplantation after simultaneous pancreaskidney transplantation compared with pancreas after kidney transplantation. Transplant Proc 39: 563-564

29. Sansalone CV, Maione G, Rossetti O, Aseni P, Soldano S, et al. (2006) Pancreas retransplantation: ideal timing and early and late results. Transplant Proc 38: 1153-1155.

30. Fazio EN, Everest M, Colman R, Wang R, Pin CL (2005) Altered Glut-2 accumulation and beta-cell function in mice lacking the exocrine-specific transcription factor, Mist1. J Endocrinol 187: 407-418.
31. Fazio EN, Pin CL (2007) Mist1-null mice are resistant to streptozotocin-induced beta cell damage. Biochem Biophys Res Commun 353: 823-828.

32. Kowalik AS, Johnson CL, Chadi SA, Weston JY, Fazio EN, et al. (2007) Mice lacking the transcription factor Mist1 exhibit an altered stress response and increased sensitivity to caerulein-induced pancreatitis. Am J Physio Gastrointest Liver Physiol 292: G1123-1132.

33. Rukstalis JM, Kowalik A, Zhu L, Lidington D, Pin CL, et al. (2003) Exocrine specific expression of Connexin32 is dependent on the basic helix-loop-helix transcription factor Mist1. J Cell Sci 116: 3315-3325.

34. Gangaram-Panday ST, Faas MM, de Vos P (2007) Towards stem-cell therapy in the endocrine pancreas. Trends Mol Med 13: 164-173.

35. Luo L, Luo JZ, Xiong F, Abedi M, Greer D (2009) Cytokines inducing bone marrow SCA+ cells migration into pancreatic islet and conversion into insulinpositive cells in vivo. Plos One 4: e4504.

36. Lombaert IM, Wierenga PK, Kok T, Kampinga HH, deHaan G (2006) Mobilization of bone marrow stem cells by granulocyte colony-stimulating facto ameliorates radiation-induced damage to salivary glands. Clin Cancer Res 12 $1804-1812$.

37. Pierre C (2004) Stem Cells Handbook. Stewart Sell ed. Totowa: Humana Press Inc.

38. Lee RH, Seo MJ, Reger RL, Jeffrey LS, Andrey AP, et al. (2006) Multipotent stromal cells from human marrow home to and promote repair of pancreatic islets and renal glomeruli in diabetic NOD/scid mice. Proc Natl Acad Sci USA 103: $17438-43$

39. AJ Friedenstein, Piatetzky-Shapiro II, Petrakova KV (1996) Osteogenesis in transplants of bone marrow cells. J Embryol Exp Morphol 16: 381-390.

40. Lennon DP, Haynesworth SE, Arm DM, Baber MA, Caplan Al (2000) Dilution of human mesenchymal stem cells with dermal fibroblasts and the effects on in vitro and in vivo osteochondrogenesis. Dev Dyn 219: 50-62.

41. Pittenger MF, Mackay AM, Beck SC, Rama KJ, Robin D, et al. (1999) Multilineage potential of adult human mesenchymal stem cells. Science 284 143-147.

42. Yoo JU, Barthel TS, Nishimura K, Solchaga L, Caplan Al, et al. (1998) The chondrogenic potential of human bone-marrow-derived mesenchymal progenitor cells. J Bone Joint Surg Am 80: 1745-1757.

43. Barry FP, Murphy JM, English K, Mahon BP (2005) Immunogenicity of adult mesenchymal stem cells: lessons from the fetal allograft. Stem Cells Dev 14 252-65.

44. Steptoe RJ, Ritchie JM, Harrison LC (2003) Transfer of hematopoietic stem cells encoding autoantigen prevents autoimmune diabetes. J Clin Invest 111 1357-1363.

45. Zhang C, Todorov I, Lin CL, Atkinson M, Kandeel F, et al. (2007) Elimination of insulitis and augmentation of islet beta cell regeneration via induction of chimerism in overtly diabetic NOD mice. Proc Natl Acad Sci U S A 104: 2337 2342

46. Choi SE, Choi KM, Yoon IH, Shin JY, Kim JS, et al. (2004) IL-6 protects pancreatic islet beta cells from pro-inflammatory cytokines-induced cell death and functional impairment in vitro and in vivo. Transpl Immunol 13: 43-53.

47. Lechner A, Yang YG, Blacken RA, Wang L, Nolan AL, et al. (2004) No evidence for significant transdifferentiation of bone marrow into pancreatic beta-cells in vivo. Diabetes 53: 616-623.

48. Mathews V, Hanson PT, Ford E, Fujita J, Polonsky KS, et al. (2004) Recruitment of bone marrow-derived endothelial cells to sites of pancreatic beta-cell injury. Diabetes 53: 91-98.

49. Wang X, Ge S, Gonzalez I, McNamara G, Rountree CB, et al. (2006) Formation of pancreatic duct epithelium from bone marrow during neonatal development. Stem Cells 24: 307-314.

50. Cabrera O, Berman DM, Kenyon NS, Ricordi C, Berggren PO, et al. (2006) The unique cytoarchitecture of human pancreatic islets has implications for islet cel function. Proc Natl Acad Sci USA 103: 2334-2339. 
Citation: Luo LG (2012) Islet Transplantation Challenge - Human Islet Longevity: A Potential Solution from Bone Marrow Cells. J Bioanal Biomed 4: e107. doi:10.4172/1948-593X.1000e107

Page 5 of 5

51. Brissova M, Fowler MJ, Nicholson WE, Chu A, Hirshberg B, et al. (2005) Assessment of human pancreatic islet architecture and composition by laser scanning confocal microscopy. J Histochem Cytochem 53: 1087-1097.

52. Luo L, Badiavas E, Luo JZ, Maizel A (2007) Allogeneic bone marrow supports human islet beta cell survival and function over six months. Biochem Biophys Res Commun 361: 859-864.

53. Luo JZ, Xiong F, Al-Homsi AS, Roy T, LG. L (2011) Human BM stem cells initiate angiogenesis in human islets in vitro. Bone Marrow Transplant 46: 1128-1137.

54. Maedler K, Sergeev P, Ris F, Oberholzer J, Joller-Jemelka HI,et al. (2002) Glucose-induced beta cell production of IL-1beta contributes to glucotoxicity in human pancreatic islets. J Clin Invest 110: 851-860.

55. Welsh N, Cnop M, Kharroubi I, Bugliani M, Lupi R, et al. (2005) Is there a role for locally produced interleukin-1 in the deleterious effects of high glucose or the type 2 diabetes milieu to human pancreatic islets? Diabetes 54: 3238-3244.
56. Wang Z, Xiong F, Hassani M, Luo JZ, Luo L (2011) Bone marrow increases human islets insulin positive cells in co-culture: quantification with flow cytometry. Journal of Diabetes Mellitus 1:109-117.

57. Kulbe H, Thompson R, Wilson JL, Robinson S, Hagemann T, et al. (2007) The inflammatory cytokine tumor necrosis factor-alpha generates an autocrine tumor-promoting network in epithelial ovarian cancer cells. Cancer Res 67 585-592.

58. Campanella GS, Grimm J, Manice LA, Colvin RA, Medoff BD, et al. (2006) Oligomerization of CXCL10 is necessary for endothelial cell presentation and in vivo activity. J Immunol 177: 6991-6998.

59. Wright DE, Bowman EP, Wagers AJ, Butcher EC, Weissman IL (2002) Hematopoietic stem cells are uniquely selective in their migratory response to chemokines. J Exp Med 195: 1145-1154.

60. Honeth G, Staflin K, Kalliomaki S, Lindvall M, Kjellman C (2006) Chemokinedirected migration of tumor-inhibitory neural progenitor cells towards an intracranially growing glioma. Exp Cell Res 312: 1265-1276. 